$$
\begin{gathered}
\text { The } \\
\text { Economic Question }
\end{gathered}
$$




\section{ECONOMICS TODAY}

\section{Edited by Andrew Leake}

The Economics Today series surveys contemporary headline topics in applied economics. Each book in the series is written by an expert in the field in a style that is fluently readable. It serves the student of introductory economic principles while also making the subject accessible to a more general reader. The series embraces the problem-solving skills of the new generation of students and stresses the importance of real-world issues and the significance of economic ideas.

\section{Published}

Andrew Leake: The Economic Question

Jean-Louis Barsoux and Peter Lawrence: The Challenge of British Management

S. F. Goodman: The European Community

Jenny Wales: Investigating Social Issues

Forthcoming

Frank Burchill: Labour Relations

\section{Series Standing Order}

If you would like to receive future titles in this series as they are published, you can make use of our standing order facility. To place a standing order please contact your bookseller or, in case of difficulty, write to us at the address below with your name and address and the name of the series. Please state with which title you wish to begin your standing order. (If you live outside the UK we may not have the rights for your area, in which case we will forward your order to the publisher concerned.)

Standing Order Service, Macmillan Distribution Ltd, Houndmills, Basingstoke, Hampshire, RG21 2XS, England. 


\title{
THE ECONOMIC QUESTION
}

\author{
Andrew Leake
}

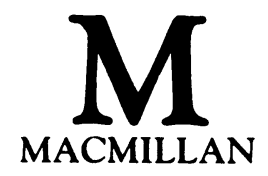


All rights reserved. No reproduction, copy or transmission of this publication may be made without written permission.

No paragraph of this publication may be reproduced, copied or transmitted save with written permission or in accordance with the provisions of the Copyright, Designs and Patents Act 1988 , or under the terms of any licence permitting limited copying issued by the Copyright Licensing Agency, 33-4 Alfred Place, London WC1E 7DP.

Any person who does any unauthorised act in relation to this publication may be liable to criminal prosecution and civil claims for damages.

First published 1990

Published by

MACMILLAN EDUCATION LTD

Houndmills, Basingstoke, Hampshire RG21 2XS

and London

Companies and representatives

throughout the world

Typeset by Latimer Trend and Company Ltd, Plymouth

British Library Cataloguing in Publication Data

Leake, Andrew

The economic question. - (Economics Today series).

1. Economics

I. Title II. Series

330

ISBN 978-0-333-53191-4 ISBN 978-1-349-20927-9 (eBook)

DOI 10.1007/978-1-349-20927-9 
For Alisoun 
Of the roote of this sevene synns, thanne, is Pride, the general roote of alle harmes. For of this roote spryngen certain braunches, as Ire (Wrath), Envye, Accidie or Slewthe (Sloth), Avarice or Coveitise (Covetousness), Glotonye, and Lecherye.

(Chaucer, 'The Parson's Tale', The Canterbury Tales, 1340) 


\section{Contents}

List of Tables and Figures xi

1 A Message to the Haves and the Have-nots 1

Why the Rich Get Richer 3

You Have Wants, I Have Needs 5

Production 7

Counting the Cost 8

Finding Room to Grow 10

Investing in the Future 11

Snakes and Ladders 13

Specialisation and Exchange 15

Which Way Forward? 17

Was the Garden of Eden Ever Really 'Green'? 19

2 Work for the Workers 20

Who Are the Unemployed? 22

A Market for Labour 23

What Jobs on Offer? 24

Labour Market Failures 26

Voluntary Unemployment 28

The Battle against Inflation $\mathbf{3 0}$

The Keynesian View 31

What's a Fair Wage? 33

How the Market Plays Fair 34

Demand and Supply Set Pay 35 
Rich and Poor 37

Shirkers and Workers: A Reinterpretation 39

3 All's Fair in ... Competition 42

The Story of a Merger $\mathbf{4 2}$

What Do Companies Do? 44

Enter Economic Theory 45

How Best to Produce 46

Prices and Marketing 49

Profit-maximising Output $\mathbf{5 0}$

Compete or Die 53

The Human Factor 54

Decision-making Skills 55

British Industry Under Competition 58

Does Deindustrialisation Matter? 60

Merger, Mania 61

Survival of the Fittest or a Lust for Power? 62

4 Market-making 65

Getting Rich Quick 66

Making Markets 67

Demand and Supply 68

Reading the Crash 70

The Roof Over Your Head 73

The Pound in Your Pocket 75

Exchange Rate Fluctuations $\mathbf{7 6}$

How to Play Markets, and Win 77

Chaos and Confusion 79

The Free Market System 81

5 To Regulate or Deregulate? 83

The Danger of Dominance 86

Policy for Monopoly 88

No Privacy These Days 90

Allowing for the Unaccountable 91

Do As You Would Be Done By 93 
The Surgical Approach 94

Benefits to Society 96

Merit Goods 97

Public Goods 99

A Case of Public Enterprise 99

Privatisation Rules 101

A State of Envy 103

6 The Money-go-round 105

Why Does Inflation Matter? 106

Where Money Comes From 108

Cash, Loans and Interest Rates 109

The Value of Money 110

Monetarism and How to Live With It 112

On Routes and Obstacles 114

Policy and Targets 115

Has Policy Succeeded? 117

Controlling Demand 119

A Cost Cutting Exercise 121

What Is the Cost of Controlling Inflation? 122

The Wrath of God 124

7 Control of the Economy - Just Good

Housekeeping? 126

Dear Prudence 128

The Targets of Government Policy 129

Jobs and Prices 130

Only the Economists Can Win 130

Measuring UK Performance 132

Taking the Good With the Bad 133

The Supply-side Approach 134

Lesser Laissez-faire 135

The Keynesian Alternative 136

Priming the Pump or Blowing the Well? 138

Open Economy Macroeconomics 139

Which Way to Turn? 140

Fashions and Failures 141 
$\mathbf{x}$ Contents

8 Economics - More Questions Than Answers? 143

Decision-making Skills 144

Economics and Fashion 146

Must Economists Disagree? 148

Slipping the Chain 150

Index 153 


\section{List of Tables and Figures}

Tables

1.1 World Living Standards 4

1.2 How Much Investment? 13

2.1 UK Unemployment 21

2.2 Pay Differences in the UK 34

2.3 The UK's Richest People 40

3.1 UK Manufacturing and Services 59

4.1 The Pound's Exchange Rate 77

5.1 UK Privatisation 85

6.1 UK Inflation 106

6.2 The Medium Term Financial Strategy 116

7.1 PSBR in the UK 127

7.2 Performance of the UK Economy 133

\section{Figures}

1.1 Production Possibilities 8

1.2 Specialisation and Trade 16

2.1 The Demand for Labour 26

2.2 Unemployment and Wages 27

2.3 Equilibrium Pay 37

3.1 Costs in the Short and Long Term 48

3.2 Profit-maximising Output 51

3.3 A Rise in Demand 52

3.4 The Decision-making Process 57

4.1 Market Equilibrium 70 

4.2 A Shift in Market Demand 71
4.3 Higher Interest Rates Cut House Prices 74
5.1 Market Dominance 87
5.2 Tax on Social Costs 94
5.3 Provision of Merit Goods 98
6.1 Money and Prices 113
6.2 Demand and Cost Inflation 120
6.3 The Phillips Curve 123
7.1 The Targets of Policy 131
7.2 The Multiplier 137 